\title{
MENINGKATKAN HASIL BELAJAR SISWA MELALUI PEMBELAJARAN DENGAN MODEL DISCOVERY LEARNING PADA SISWA KELAS X MIPA 5 SMA N 1 BANTUL TAHUN PELAJARAN 2018/2019
}

\author{
Oleh: Sutrisno \\ SMA N 1 Bantul \\ Email: trihidayatai12@gmail.com
}

\begin{abstract}
This study aims (1) to describe the learning process with Discovery Learning models among students; and (2) Improve the learning outcomes in subject of Bahasa Indonesia by application of discovery learning models. The subjects of this study were students of class X MIPA 5 SMA N 1 Bantul at 2018/2019 Academic Year. The study was conducted in three months from January to the end of March 2019. This study was a classroom action research (CAR), carried out in two cycles. Each cycle consists of four activities: (1) planning, (2) implementation, (3) observation, and (4) reflection. There are five types of data collection techniques used in this study, i.e. (1) observation, (2) questionnaire, (3) guided interviews, and (4) documentation. The results of this study show that (1) Discovery learning learning models improved teacher performance in learning, improved the performance of students in learning, and obtained excellent responses from students; (2) Implementation of discovery learning models improved student learning outcomes. The average value of student learning outcomes with the discovery learning model in cycle I was 82 with sufficient predicate, then increased to 94 in cycle II with very good predicate. The learning completeness in cycle I was $81.25 \%$ and increased to $100 \%$ in cycle II.
\end{abstract}

Keywords: discovery learning, teacher performance, student performance, student responses, learning outcomes

\section{PENDAHULUAN}

Pembelajaran bahasa Indonesia diarahkan untuk meningkatkan kemampuan peserta didik dalam berkomunikasi dengan bahasa Indonesia secara baik dan benar, baik lisan maupun tulis, serta menumbuhkan apresiasi terhadap hasil karya kesastraan Indonesia. Dengan pembelajaran Bahasa Indonesia, peserta didik dapat menguasai pengetahuan, keterampilan berbahasa, dan sikap positif terhadap bahasa dan sastra Indonesia. Hal tersebut merupakan dasar bagi peserta didik untuk memahami dan merespons situasi lokal, regional, nasional, dan global.

Kurikulum 2013 mewajibkan guru untuk melaksanakan pembelajaran dengan menggunakan pendekatan saintifik/ilmiah, yaitu pembelajaran yang mengadopsi langkahlangkah saintis dalam membangun pengetahuan melalui metode ilmiah.
Pendekatan ini menekankan pada proses pencarian pengetahuan, berkenaan dengan materi pembelajaran melalui kegiatan mengamati (observing), menanya (questioning), mengumpulkan informasi/ mencoba (experimenting), mengasosasi (associating), dan mengomunikasikan (communicating).

Lampiran Permendikbud Nomor 103 Tahun 2014 tentang Pembelajaran pada Pendidikan Dasar dan Menengah menyatakan bahwa, model pembelajaran merupakan suatu bentuk pembelajaran yang memiliki nama, ciri, sintak, pengaturan, dan budaya. Ada beberapa model pembelajaran yang sesuai dengan karakteristik pendekatan saintifik Kurikulum 2013, seperti discovery learning, project-based learning, problem-based learning, dan inquiry learning.

Dalam realitanya, pembelajaran Bahasa Indonesia pada kelas X MIPA 5 SMA N 1 
Bantul belum memenuhi peran dan tujuan pembelajaran Bahasa Indonesia sebagaimana diapaparkan di atas. Hal ini tampak dari beberapa indikator seperti : (1) Pembelajaran sebagai proses interaksi antarpeserta didk belum berbasis pada aktivitas peserta didik; (2) Kegiatan pembelajaran kurang menyenangkan, kurang menantang, dan kurang memotivasi peserta didik untuk berpartisipasi aktif; (3) Pembelajaran tidak kontekstual dan tidak kolaboratif; (4) Proses pembelajaran belum memberikan ruang yang cukup bagi prakarsa, kreativitas, dan kemandirian peserta didik; (5) pembelajaran belum sesuai dengan bakat, minat, kemampuan, dan perkembangan fisik serta psikologis peserta didik; (6) Hasil belajar peserta didik belum optimal.

Beberapa faktor penyebab munculnya permasalahan dalam pembelajaran Bahasa Indonesia pada kelas X SMA N 1 Bantul adalah : (1) sistem zonasi pada penerimaan peserta didik baru yang diterapkan pada tahun pelajaran 2018/2019 berakibat pada heterogennya kemampuan akademik peserta didik; (2) pembelajaran berpusat pada guru; (3) motivasi belajar peserta didik yang kurang; (4) materi pembelajaran kurang menantang; dan (5) guru belum menerapkan model pembelajaran yang berbasis pada pendekatan saintifik.

Di antara beberapa indikator permasalahan pembelajaran Bahasa Indonesia di atas, berdasarkan hasil pengamatan, wawancara dengan peserta didik, dan refleksi, permasalahan utama yang menyebabkan pembelajaran Bahasa Indonesia belum memenuhi tujuan dan harapan adalah pembelajaran Bahasa Indonesia kurang menyenangkan, kurang memotivasi peserta didik serta hasil belajar peserta didik yang belum optimal. Faktor penyebab utamanya adalah guru belum secara optimal menerapkan model pembelajaran yang berbasis pada pendekatan saintifik.
Salah satu model pembelajaran yang berbasis pada pendekatan saintifik adalah discovery learning. Model pembelajaran discovery learning adalah model pembelajaran yang memberikan kesempatan kepada peserta didik untuk mencari tahu tentang suatu permasalahan dan menemukan solusinya berdasarkan hasil pengolahan informasi yang dicari dan dikumpulkannya sendiri sehingga peserta didik memiliki pengetahuan baru yang dapat digunakannya dalam memecahkan persoalan yang relevan (Kemendikbud, 2015: 10). Dengan model ini, pengetahuan dan keterampilan yang diperoleh peserta didik diharapkan bukan hanya dihasilkan dari mengingat seperangkat faktafakta, tetapi lebih dari pada itu, yakni dihasilkan dari menemukan sendiri (Sugiyanta, 2015: 5).

Dalam mengaplikasikan model pembelajaran discovery learning, guru berperan sebagai pembimbing dengan memberikan kesempatan kepada peserta didik untuk belajar secara aktif. Dengan model ini, bahan ajar tidak disampaikan dalam bentuk akhir, akan tetapi peserta didik dituntut untuk melakukan berbagai kegiatan menghimpun informasi, membandingkan, mengategorikan, menganalisis, mengintegrasikan, mereorganisasikan bahan pelajaran, dan membuat kesimpulan (Badan Pengembangan Sumber Daya Pendidikan dan Kebudayaan dan Penjaminan Mutu Pendidikan, 2014 : 67).

Pemanfaatan model discovery learning dalam pembelajaran Bahasa Indonesia dengan demikian diyakini akan dapat membuat pembelajaran Bahasa Indonesia menyenangkan dan menantang sehingga dapat meningkatkan motivasi dan hasil belajar.

Penelitian ini bertujuan untuk mendeskripsikan: (1) Proses pembelajaran dengan model pembelajaran discovery learning untuk meningkatkan hasil belajar peserta didik kelas X MIPA 5 SMA N 1 Bantul tahun pelajaran 2018/2019 dan (2) Peningkatan hasil belajar peserta didik kelas $\mathrm{X}$ 
MIPA 5 SMA N 1 Bantul tahun pelajaran 2018/2019 dalam pembelajaran Bahasa Indonesia dengan model discovery learning.

Agar tidak terjadi kesalahpahaman, berikut diberikan definisi operasional beberapa istilah yang digunakan dalam penelitian tidakan kelas ini yaitu : (1) Discovery learning adalah model pembelajaran yang memberikan kesempatan kepada peserta didik untuk mencari tahu tentang suatu permasalahan dan menemukan solusinya berdasarkan hasil pengolahan informasi yang dicari dan dikumpulkannya sendiri, sehingga peserta didik memiliki pengetahuan baru yang dapat digunakannya dalam memecahkan persoalan yang relevan; terdiri atas enam sintak yaitu stimulation (memberi stimulus), problem statement (mengidentfikasi masalah), data collecting (pengumpulan data), data processing (mengolah data), verification (memverifikasi), dan generalization (generalisasi); (2) Proses pembelajaran adalah deskripsi tentang kinerja guru, kinerja peserta didik, dan tanggapan peserta didik dalam pembelajaran dengan model discovery learning; (3) Hasil belajar adalah hasil penilaian terhadap kompetensi peserta didik dalam pembelajaran Bahasa Indonesia dengan materi teks biografi pada Kompetensi Dasar (KD) 3.14 dan 4.14 (menilai hal yang dapat diteladani dari tokoh teks biografi) dan KD 3.15 dan 4.15 (menganalisis makna dan kebahasaan teks biografi); dan (4) Peserta didik adalah siswa kelas X MIPA 5 SMA N 1 Bantul tahun pelajaran 2018/2019 sebanyak 32 siswa.

\section{Hasil Belajar}

Dalam pandangan Dimyati dan Mudjiono (2006: 3) hasil belajar merupakan hasil dari suatu interaksi tindakan belajar dan tindakan mengajar. Sementara itu, Sudjana (2001: 21) mengungkapkan bahwa hasil belajar adalah kemampuan yang dimiliki peserta didik setelah ia memiliki pengalaman belajarnya. Surya (2008: 86) meihat hasil belajar sebagai perubahan tingkah laku.
Menurutnya, hasil belajar ditandai dengan perubahan tingkah laku secara keseluruhan. Perubahan tingkah laku sebagai hasil belajar meliputi aspek tingkah laku kognitif, konotatif, afektif atau motorik. Belajar yang hanya menghasilkan perubahan satu atau dua aspek tingkah laku saja disebut belajar sebagian dan bukan belajar lengkap. Hamalik (2007: 30) menyatakan bahwa hasil belajar sebagai terjadinya perubahan tingkah laku yang dapat diamati dan diukur dalam bentuk pengeyahuan, sikap, dan keterampolan. Perubahan tersebut dapat diartikan sebagai terjadinya peningkatan dan pengetahuan yang lebih baik dari sebelumnya, dari yang tidak tahu menjadi tahu.

Hasil belajar adalah pola-pola perbuatan, nilai-nilai, pengertian-pengertian, sikap-sikap, apresiasi dan keterampilan yang berupa: (1) informasi verbal yaitu kapabilitas mengungkapkan pengetahuan dalam bentuk bahasa, baik lisan maupun tertulis, (2) keterampilan intelektual yaitu kemampuan mempresentasikan konsep dan lambang atau kemampuan melakukan aktivitas kognitif bersifat khas, (3) strategi kognitif yaitu kecakapan menyalurkan dan mengarahkan aktivitas kognitifnya sendiri, (4) keterampilan motorik yaitu kemampuan melakukan serangakaian gerak jasmani, dan (5) sikap adalah kemampuan menginternalisasi dan mengeksternalisasi nilai-nilai (Suprijono, 2010: 6).

Hasil belajar dengan demikian dapat disimpulkan sebagai kemampuan yang dimiliki peserta didik setelah melewati proses belajar. Hasil belajar adalah puncak dari keberhasilan belajar peserta didik terhadap tujuan belajar yang telah ditetapkan, hasil belajar peserta didik dapat meliputi aspek kognitif (pengetahuan), afektif (sikap), dan psikomotorik (keterampilan). Hasil belajar merupakan proses yang cukup kompleks, hasil belajar peserta didik dipengaruhi oleh beberapa faktor yang mendukung, yaitu (1) faktor internal, meliputi faktor fisiologis dan 
psikologis; dan (2) faktor eksternal, meliputi faktor lingkungan sosial dan nonlingkungan sosial, peran peserta didik, peran guru, serta model yang digunakan dalam pembelajaran (Slameto, 2010).

\section{Pembelajaran Teks Biografi}

Sebagaimana diamanatkan oleh Permendikbud Nomor 24 Tahun 2016 tentang Kompetensi Inti dan Kompetensi Dasar Pelajaran pada Kurikulum 2013, dalam pembelajaran Bahasa Indonesia materi teks biografi terdapat pada Kompetensi Dasar (KD) yang tersaji pada tabel berikut.

Tabel 1. KD 3.14, 4.14 dan 3.15. 4.15

Bahasa Indonesia Kelas X SMA K-13

\begin{tabular}{cl}
\hline No. KD & \multicolumn{1}{c}{ KD } \\
\hline 3.14 & $\begin{array}{l}\text { Menilai hal yang dapat diteladani } \\
\text { dari teks biografi. }\end{array}$ \\
\hline 4.14 & $\begin{array}{l}\text { Mengungkapkan kembali hal-hal } \\
\text { yang dapat diteladani dari tokoh } \\
\text { yang terdapat dalam teks biografi } \\
\text { yang dibaca secara tertulis. }\end{array}$ \\
\hline 3.15 & $\begin{array}{l}\text { Menganalisis aspek makna dan } \\
\text { kebahasaan dalam teks biografi. }\end{array}$ \\
\hline 4.15 & $\begin{array}{l}\text { Menceritakan kembali isi teks } \\
\text { biografi baik lisan maupun tulis. }\end{array}$ \\
\hline
\end{tabular}

Dalam Kamus Besar Bahasa Indonesia (KBBI), biografi diartikan sebagai riwayat hidup seseorang yang ditulis oleh orang lain. Dalam biografi disajikan sejarah hidup, pengalaman-pengalaman, sampai kisah sukses orang yang sedang diulas. Umumnya biografi menampilkan tokoh-tokoh terkenal, orang sukses, atau orang yang telah berperan besar dalam suatu hal yang menyangkut kehidupan orang banyak. Membaca sebuah biografi akan memperkaya wawasan dan sebagai teladan agar dapat menjalani kehidupan dengan baik dan mengisi hidup dengan karya yang bermanfaat tidak hanya bagi diri sendiri, tetapi juga orang lain. Teks biografi dengan demikian merupakan teks yang berisi riwayat hidup seseorang yang ditulis oleh orang lain (Kosasih, 2014: 154).

Teks biografi termasuk teks narasi. Oleh karena itu struktur teks biografi juga sama dengan teks cerita ulang lainnya seperti cerpen dan hikayat yaitu orientasi, kejadian penting, reorientasi (Suherli dkk, 2017: 215).

a) Orientasi atau setting (aim), berisi informasi mengenai latar belakang kisah atau peristiwa yang akan diceritakan selanjutnya untuk membantu pendengar/pembaca. Informasi yang dimaksud berkenaan dengan ihwal siapa, kapan, di mana, dan bagaimana.

b) Kejadian penting (important event, record of events), berisi rangkaian peristiwa yang disusun secara kronologis, menurut urutan waktu, yang meliputi kejadian-kejadian utama yang dialami tokoh. Dalam bagian ini mungkin pula disertakan komentar-komentar pencerita pada beberapa bagiannya.

c) Reorientasi, berisi komentar evaluatif atau pernyataan simpulan mengenai rangkaian peristiwa yang telah diceritakan sebelumnya. Bagian ini sifatnya opsional, yang mungkin ada atau tidak ada di dalam teks biografi.

Pola penyajian teks biografi dapat dilihat dari alur, sudut pandang penceritaan, gaya penceritaan, dan fokus penceritaan. Biografi biasanya menggunakan alur majun maju (dari peristiwa masa lalu ke masa kini); menggunakan sudut pandang orang ketiga serba tahu; gaya peceritaan dilakukan dengan cara deskriptif naratif atau gabungan antara deskriptif naratif dan dialog.dan fokus penceritaan dapat menceritakan identitas pribadi (asal-usul keluarga), pendidikan, perjalanan karier, maupun prestasi yang berhasil diraih (Suherli dkk, 2017: 294).

Tokoh yang riwayat hidupnya ditulis dalam biografi biasanya memiliki kepribadian unggul, lebih dibandingkan orang lain. Kepribadian unggul inilah yang biasanya mampu mengantarkan seseorang mencapai keberhasilan dalam kehidupannya. Untuk dapat mengidentifikasi kepribadian unggul seseorang kita dapat melihat dari peristiwa/permasalahan apa yang dialami seseorang serta bagaimana caranya 
menghadapi semua itu.Kepribadian unggul yang dimiliki tokoh pada teks biografi merupakan karakter unggul yang dapat diteladani pembaca dalam kehidupan sehari-hari.Dalam menyampaikan karakter unggul tokoh, penulis dapat menggunakan cara yang berbeda. Ada yang disampaikan secara langsung dan ada yang dilakukan secara deskriptif (Suherli dkk, 2017: 302).

Teks biografi menggunakan beberapa kaidah kebahasaan yang dominan sebagai berikut (Suherli dkk, 2017: 306).

1) Menggunakan kata ganti orang ketiga tunggal ia atau dia atau beliau. Kata ganti ini digunakan secara bervarisi dengan penyebutan nama tokoh/panggilan tokoh.

2) Banyak menggunakan kata kerja tindakan untuk menjelaskan peristiwaperistiwa atau perbuatan fisik yang dilakukan oleh tokoh. Contoh: belajar, membaca, berjalan, melempar.

3) Banyak menggunakan kata deskriptif untuk memberikan informasi secara rinci tentang sifat-sifat tokoh. Kata-kata yang dimaksud. Contoh: kata sifat untuk mendeskripsikan watak tokoh antara lain genius, rajin, ulet. Dalam melakukan deskripsi, seringkali penggunaan kata sifat didahului oleh kopulatif adalah, merupakan.

4) Banyak menggunakan kata kerja pasif untuk menjelaskan peristiwa yang dialami tokoh sebagai subjek yang diceritakan. Contoh: diberi, ditugaskan, dipilih.

5) Banyak menggunakan kata kerja mental dalam rangka penggambaran peran tokoh. Contoh memahami, menyetujui, menginspirasi, mencintai.

6) Banyak menggunakan kata sambung, kata depan, ataupun nomina yang berkenaan urutan dengan waktu. Contoh: sebelum, sudah, pada saat, kemudian, selanjutnya,sampai, hingga, pada tanggal, nantinya, selama, saat itu.

\section{Model Pembelajaran Discovery Learning}

Hosnan (2014: 282) mengungkapkan bahwa discovery learning adalah suatu model untuk mengembangkan cara belajar aktif dengan menemukan sendiri, menyelidiki sendiri sehingga hasil yang diperoleh akan setia dan tahan lama dalam ingatan. Melalui belajar penemuan, peserta didik juga bisa belajar berpikir analisis dan mencoba memecahkan sendiri masalah yang dihadapi. Wilcox (dalam Hosnan, 2014: 281) menyatakan bahwa dalam pembelajaran dengan penemuan, peserta didik didorong untuk belajar sebagian besar melalui keterlibatan aktif mereka sendiri dengan konsep-konsep dan prinsip-prinsip dan guru mendorong peserta didik untuk memiliki pengalaman dan melakukan percobaan/ pengamatan yang memungkinkan mereka menemukan prinsip-prinsip untuk diri mereka sendiri.

Penemuan (discovery) merupakan suatu model pembelajaran yang dikembangkan berdasarkan pandangan konstruktivisme. Maharani dan Hardini (2017: 552) mengungkapkan bahwa discovery learning berupa proses pembelajaran yang penyampaian materinya tidak utuh, karena model discovery learning menuntut peserta didik terlibat aktif dalam proses pembelajaran dan menemukan sendiri suatu konsep pembelajaran.

Discovery learning merupakan model yang mengarahkan peserta didik menemukan konsep melalui berbagai informasi/data yang diperoleh melalui pengamatan atau percobaan. Menurut Sani (2014: 97-98), discovery learning merupakan proses dari inkuiri. Discovery yaitu menemukan konsep melalui serangkaian data/ informasi yang diperoleh dengan pengamatan atau percobaan. Discovery learning menuntut guru lebih kreatif menciptakan situasi yang membuat peserta didik belajar aktif dan menemukan pengetahuan sendiri.

Model pembelajaran discovery learning dengan demikian merupakan model 
pembelajaran yang memberikan kesempatan kepada peserta didik untuk mencari tahu tentang suatu permasalahan dan menemukan solusinya berdasarkan kepada hasil pengolahan informasi yang dicari dan dikumpulkannya sendiri, sehingga peserta didik memiliki pengetahuan baru yang dapat digunakannya dalam memecahkan persoalan yang relevan (Kemendikbud, 2015: 10). Ciri utama discovery learning adalah (1) berpusat pada peserta didik; (2) mengeksplorasi dan memecahkan masalah untuk menciptakan, menghubungkan, dan menggeneralisasi pengetahuan; serta (3) kegiatan untuk menggabungkan pengetahuan baru dan pengetahuan yang sudah ada.

Dalam discovery learning, guru berperan sebagai pembimbing dengan memberikan kesempatan kepada peserta didik untuk belajar secara aktif sesuai tujuan pembelajaran. Kegiatan belajar mengajar yang teacher oriented menjadi student oriented (Sardiman, 2005: 145). Dengan mengaplikasikan model discovery learning, kemampuan penemuan peserta didik akan meningkat. Kondisi belajar yang pasif akan menjadi aktif dan kreatif. Mengubah modus ekspositori peserta didik hanya menerima informasi secara keseluruhan dari guru menjadi modus discovery, peserta didik menemukan sendiri (Pusat Pengembangan Profesi Pendidik, 2014: 66)

Ada enam langkah/sintak model pembelajaran discovery learning (Kemendikbud, 2015: 10).

\section{1) Stimulation}

Guru memberikan stimulan, untuk diamati peserta didik agar mendapat pengalaman belajar mengamati pengetahuan konseptual melalui kegiatan membaca, mengamati situasi atau melihat gambar.

\section{2) Problem Statement}

Kegiatan peserta didik dalam menemukan permasalahan apa saja yang dihadapi, sehingga pada kegiatan ini peserta didik diberikan pengalaman untuk menanya, mencari informasi, dan merumuskan masalah. 3) Data Collecting

Mencari dan mengumpulkan data/informasi yang dapat digunakan untuk menemukan solusi pemecahan masalah yang dihadapi. Kegiatan ini juga akan melatih ketelitian, akurasi, dan kejujuran, serta membiasakan peserta didik untuk mencari atau merumuskan berbagai alternatif pemecahan masalah, jika satu alternatif mengalami kegagalan.

4) Data Processing

Peserta didik mencoba dan mengeksplorasi kemampuan pengetahuan konseptualnya untuk diaplikasikan pada kehidupan nyata, sehingga kegiatan ini juga akan melatih keterampilan berfikir logis dan aplikatif.

5) Verification

Peserta didik mengecek kebenaran atau keabsahan hasil pengolahan data melalui berbagai kegiatan atau mencari sumber yang relevan baik dari buku atau media, serta mengasosiasikannya sehingga menjadi suatu kesimpulan.

\section{6) Generalization}

Peserta didik digiring untuk menggeneralisasikan hasil kesimpulannya pada suatu kejadian atau permasalahan yang serupa, sehingga kegiatan ini juga dapat melatih pengetahuan metakognisi peserta didik.

\section{Hipotesis Tindakan}

Penerapan model pembelajaran discovery learning dapat meningkatkan proses dan hasil belajar peserta didik.

\section{METODOLOGI PENELITIAN}

Subjek penelitian ini adalah peserta didik kelas X MIPA 5 SMA N 1 Bantul. Tahun Pelajaran 2018/2019. Seting/lokasi penelitian adalah SMA N 1 Bantul, Jalan K.H. Wakhid Hasyim Bantul, Yogyakarta. Sedangkan 
waktu penelitian selama tiga bulan terhitung dari bulan Januari sampai akhir Maret 2019.

Penelitian ini termasuk jenis penelitian tindakan kelas (PTK). Penelitian ini dilaksanakan dalam dua siklus. Tiap siklus terdiri dari empat tahap yaitu: (1) perencanaan tindakan, (2) pelaksanaan tindakan, (3) pengamatan/observasi, dan (4) refleksi.

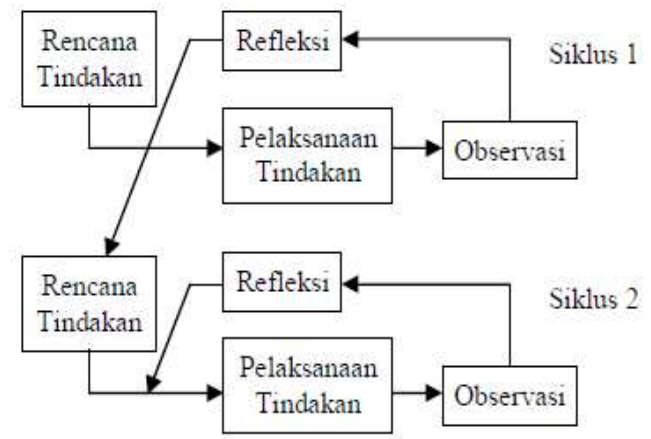

Gambar 1. Desain/Rancangan Penelitian Tindakan Kelas (PTK)

Ada lima macam teknik pengumpulan data yang digunakan yaitu : (1) observasi, digunakan untuk mengumpulkan data mengenai kinerja guru dan peserta didik dalam pembelajaran model discovery learning; (2) Angket, digunakan untuk mengumpulkan data tanggapan peserta didik terhadap implementasi model pembelajaran discovery learning; (3) Wawancara Terpimpin, digunakan untuk memperkuat data yang diperoleh dari hasil observasi dan angket; (4) Tes, dipergunakan untuk menilai hasil belajar peserta didik setelah mengikuti pembelajaran dengan menggunakan model pembelajaran discovery learning; dan (5) Dokumentasi, digunakan untuk mengumpulkan bukti pelaksanaan pembelajaran dengan menggunakan model discovery learning baik berupa tugas peserta didik, foto aktivitas peserta didik dan guru, serta penilaian hasil belajar peserta didik.

Teknik analisis data yang digunakan dalam penelitian ini adalah teknik deskriptif kuantitatif dan kualitatif. Data kuantitatif didapatkan dari hasil observasi kinerja guru dalam pembelajaran dengan model discovery learning, hasil observasi kinerja peserta didik dalam pembelajaran dengan model discovery learning, hasil angket tanggapan peserta didik terhadap impelementasi pembelajaran dengan model discovery learning dan tes hasil belajar peserta didik. Data ini disajikan dalam bentuk angka yang kemudian dijelaskan secara deskriptif. Sedangkan data kualitatif adalah data yang diperoleh dari hasil wawancara dengan beberapa peserta didik mengenai tanggapan peserta didik terhadap implementasi discovery learning.

\section{Indikator Keberhasilan Tindakan}

Indikator keberhasilan dalam penelitian tindakan ini yaitu :

1. Nilai kinerja guru dalam pembelajaran model discovery learning $\geq 92$ dengan predikat amat baik.

2. Nilai kinerja peserta didik dalam pembelajaran model discovery learning $\geq$ 85 dengan predikat baik.

3. Nilai hasil belajar peserta didik $\geq 85$ dengan predikat baik dan ketuntasan belajar klasikal mencapai $100 \%$ dengan Kriteria Ketuntasan Minimal 75.

\section{HASIL DAN PEMBAHASAN}

\section{Kinerja Guru dalam Pembelajaran dengan} Model Discovery Learning

Pembelajaran dengan model discovery learning menuntut guru untuk memiliki kemampuan yang memadai dalam mengorganisasi pembelajaran dari kegiatan pendahuluan, penguasaan materi, implementasi model discovery learning, pemanfaatan media dan sumber belajar, interaksi dengan peserta didik, penggunaan bahasa yang benar dan tepat, dan penutup.

Terutama pada aspek implementasi dalam pembelajaran, guru harus mampu menerapkan tahapan pembelajaran sesuai sintak model pembelajaran dengan model discovery learning yaitu (1) stimulation (memberi stimulus), guru memberikan stimulant kepada peserta didik agar mendapat pengalaman belajar mengamati pengetahuan konseptual; (2) problem statement 
(mengidentifikasi masalah), guru mendampingi peserta didik mengidentifikasi secara kritis berbagai permasalahan terkait materi pembelajaran; (3) data collecting (mengumpulkan data), guru memfasilitasi peserta didik untuk mencari dan mengumpulkan data/informasi; (4) data processing (mengolah data), guru memberikan kesempatan kepada peserta didik muntuk mengolah data yang diperoleh; (5) verification (memverifikasi), guru membimbing peserta didik mengecek kebenaran atau keabsahan hasil pengolahan data dengan kritis dan kreatif mencari sumber yang relevan baik dari buku atau internet, serta mengasosiasikannya sehingga menjadi suatu kesimpulan, mempersilakan peserta didik bersama anggota kelompoknya mempresentasikan hasil diskusi kelompok, serta memperhatikan peserta didik memberikan tanggapan atas pertanyaan, masukan, dan sanggahan dari kelompok lain; dan (6) generalization (menyimpulkan), guru membimbing peserta didik menyimpulkan materi pembelajaran yang dipresentasikan.

Dari hasil penelitian sebagaimana tersaji pada tabel 2 tampak jelas terjadi perubahan kinerja guru dalam pembelajaran dengan model discovery learning pada siklus I dan siklus II. Pada siklus I, kinerja guru dalam pembeajaran dengan model discovery learning, nilai aspek kegiatan pendahuluan 80 dengan predikat cukup, pada siklus II meningkat menjadi 100 dengan predikat amat baik; nilai aspek implementasi pembelajaran dengan model discovery learning 89 dengan predikat baik, pada siklus II meningkat menjadi 100 dengan predikat amat baik; nilai aspek pemanfaatan media dan sumber belajar 83 dengan predikat baik, pada siklus II meningkat menjadi 100 dengan predikat amat baik; dan nilai aspek interaksi dengan peserta didik 80 dengan predikat cukup baik, pada siklus II meningkat menjadi 100 dengan predikat amat baik. Sementara itu, nilai optimal 100 dengan predikat amat baik pada siklus I untuk aspek penguasaan materi pembelajaran, penggunaan bahasa yang benar dan tepat, serta kegiatan penutup dapat dipertahankan dengan nilai dan predikat yang sama pada siklus II.

Tabel 2. Kinerja Guru dalam Pembelajaran Model Discovery Learning pada Siklus I dan II

\begin{tabular}{|c|c|c|c|c|c|}
\hline \multirow{2}{*}{ No. } & \multirow{2}{*}{ Aspek yang Diamati } & \multicolumn{2}{|c|}{ Siklus I } & \multicolumn{2}{|c|}{ Siklus II } \\
\hline & & Nilai & Predikat & Nilai & Predikat \\
\hline 1. & Kegiatan pendahuluan & 80 & Cukup Baik & 100 & Amat Baik \\
\hline 2. & Penguasaan materi pembelajaran & 100 & Amat Baik & 100 & Amat Baik \\
\hline 3. & Implementasi model discovery learning & 89 & Baik & 100 & Amat Baik \\
\hline 4. & Pemanfaatan media dan sumber belajar & 83 & Baik & 100 & Amat Baik \\
\hline 5. & Interaksi dengan peserta didik & 80 & Cukup Baik & 100 & Amat Baik \\
\hline 6. & Penggunaan bahasa yang benar dan tepat & 100 & Amat Baik & 100 & Amat Baik \\
\hline 7 & Kegiatan penutup & 100 & Amat Baik & 100 & Amat Baik \\
\hline & Nilai Kinerja Guru & 89 & Baik & 100 & Amat Baik \\
\hline
\end{tabular}

Dilihat dari rerata nilai kinerja peserta guru dalam pembelajaran model discovery learning sebagaimana tersaji pada gambar 2 , tampak terjadi peningkatan pada siklus II dibandingkan dengan siklus I. Rerata nilai kinerja guru dengan model discovery learning pada siklus I sebesar 89 dengan perdikat baik meningkat menjadi 100 dengan predikat amat baik pada siklus II. Terjadi peningkatan nilai kinerja peserta didik sebesar 11 .

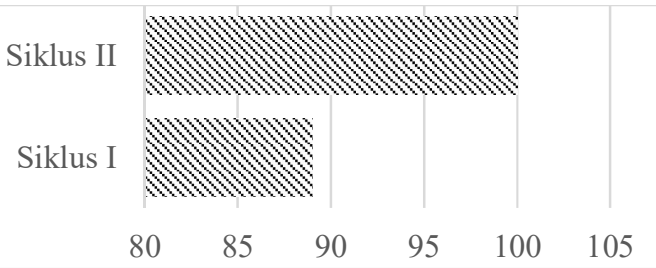

Gambar 2. Peningkatan Kinerja Guru dalam Pembelajaran Model Discovery Learning Terjadinya peningkatan nilai kinerja guru dalam pembelajaran dengan model 
discovery learning tidak terlepas dari masukan dan solusi yang diberikan kolaborator terhadap kelemahan peneliti dalam pembelajaran dengan model discovery learning pada siklus I. Selanjutnya peneliti berupaya memperbaiki kelemahan terutama pada aspek kegiatan pendahuluan, implementasi model pembelajaran discovery learning, pemanfaatan media dan sumber belajar, dan interaksi dengan peserta didik. Dengan upaya dan kemauan yang keras, pada siklus II semua aspek kinerja guru dalam pembelajaran dengan model discovery learning dapat mencapai nilai 100 dengan predikat amat baik.

Hal ini sesuai dengan pendapat Sani (2014: 97-98), bahwa discovery learning merupakan proses dari inkuiri. Discovery adalah menemukan konsep melalui serangkaian data atau informasi yang diperoleh dengan pengamatan atau percobaan. Discovery learning merupakan metode belajar yang menuntut guru lebih kreatif menciptakan situasi yang membuat peserta didik belajar aktif dan menemukan pengetahuan sendiri.

Kinerja Peserta Didik dalam Pelaksanaan Pembelajaran dengan Discovery Learning

Pembelajaran dengan model discovery learning menuntut peserta didik untuk melaksanakan aktivitas pembelajaran dengan kritis, kreatif, kolaboratif, dan komunikatif.
Kinerja peserta didik dalam pembelajaran dengan model discovery learning terlihat dari kemampuan peserta didik pada aspek/komponen (1) mengidentifikasi masalah dan penyebabnya untuk diungkap; (2) pemilihan sumber informasi (referensi) sebagai dasar penemuan; (3) pemilihan strategi penyelesaian masalah; (4) pemilihan metode pencarian data; (5) cara pengolahan data; (6) cara penarikan simpulan berdasarkan data; (7) kualitas simpulan; (8) kegunaan simpulan dalam menyelesaikan masalah; dan (9) presentasi hasil penemuan.

Berdasarkan hasil penelitian sebagaimana tersaji pada tabel 3 tampak jelas terjadi perubahan kinerja peserta didik dalam pembelajaran dengan model discovery learning pada siklus I dan siklus II. Pada siklus I, peserta didik dengan kinerja pembelajaran model discovery learning yang berpredikat amat baik berjumlah 4 orang $(12,50 \%)$ pada siklus II meningkat menjadi 7 orang $(21,88 \%)$. Peserta didik dengan kinerja pembelajaran model discovery learning yang berpredikat baik pada siklus I berjumlah 20 orang $(62,5 \%)$ meningkat menjadi 25 orang $(78,12 \%)$ pada siklus II. Sementara itu, pada siklus I peserta didik yang memiliki kinerja cukup baik (25\%), pada siklus II tidak lagi terdapat peserta didik dengan kinerja cukup baik.

Tabel 3. Kinerja Peserta Didik dalam Pembelajaran Model Discovery Learning pada Siklus I dan II

\begin{tabular}{clcccc}
\hline \multirow{2}{*}{ No. } & Predikat Kinerja Peserta Didik dalam & \multicolumn{2}{c}{ Siklus I } & \multicolumn{2}{c}{ Siklus II } \\
\cline { 3 - 6 } & Pembelajaran Model Discovery Learning & Jumlah & Persentase & Jumlah & Persentase \\
\hline 1 & Amat Baik & 4 & $12,50 \%$ & 7 & $21,88 \%$ \\
\hline 2 & Baik & 20 & $62,50 \%$ & 25 & $78.12 \%$ \\
\hline 3 & Cukup Baik & 8 & $25 \%$ & 0 & $0 \%$ \\
\hline 4 & Kurang Baik & 0 & $0 \%$ & 0 & $0 \%$ \\
\hline & Nilai Kinerja Peserta Didik & \multicolumn{2}{c}{84,10} & \multicolumn{2}{c}{88,13} \\
\hline & Predikat & Baik & Baik \\
\hline
\end{tabular}

Dilihat dari rerata nilai kinerja peserta didik dalam pembelajaran model discovery learning sebagaimana tersaji pada gambar 3 , terjadi peningkatan pada siklus II dibanding siklus I. Rerata nilai kinerja peserta didik dengan model discovery learning pada siklus I sebesar 84,10 dengan perdikat baik meningkat menjadi 88,13 dengan predikat baik pada siklus II. Terjadi peningkatan nilai kinerja peserta didik sebesar 4,3. 


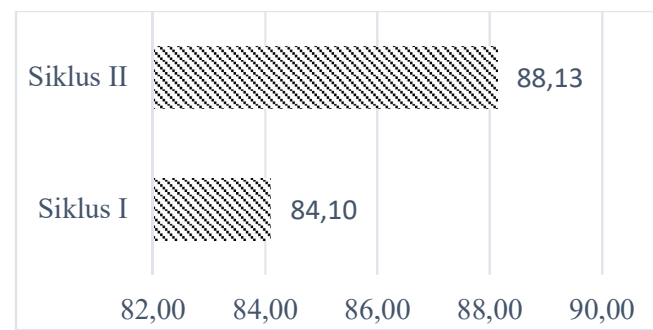

Gambar 3. Peningkatan Kinerja Peserta Didik dalam Pembelajaran Model Discovery Learning

Peningkatan nilai kinerja peserta didik ini tidak terlepas dari peningkatan kinerja guru dalam pembelajaran dengan model discovery learning. Guru telah mampu mengimplementasikan pembelajaran berdasarkan model discovery learning dengan amat baik dari kegiatan pendahuluan, penguasaan materi pembelajaran, implementasi model pembelajaran discovery learning, pemanfaatan media dan sumber belajar, interaksi dengan peserta didik, penggunaan bahasa yang benar dan tepat, dan kegiatan penutup.

Terjadinya peningkatan nilai kinerja peserta didik dalam pembelajaran dengan model discovery learning semakin menguatkan apa yang disampaikan oleh Sugiyanta (2015 : 5) dan Kemendikbud (2015: 10) bahwa model pembelajaran discovery learning merupakan model pembelajaran yang memberikan kesempatan kepada peserta didik untuk mencari tahu tentang suatu permasalahan dan menemukan Tabel 4. Hasil Belajar Peserta Didik dalam Pembelajaran Model Discovery Learning Siklus I dan II

\begin{tabular}{|c|c|c|c|c|c|}
\hline \multirow{2}{*}{ No } & \multirow{2}{*}{ Hasil Tes } & \multicolumn{2}{|r|}{ Siklus I } & \multicolumn{2}{|r|}{ Siklus II } \\
\hline & & Nilai & Predikat & Nilai & Predikat \\
\hline 1 & Nilai Tertinggi & 95 & Amat Baik & 100 & Amat Baik \\
\hline 2 & Nilai Terendah & 60 & Kurang Baik & 78 & Cukup Baik \\
\hline 3 & Rata-Rata & 82 & Cukup & 94 & Amat Baik \\
\hline 4 & Persentase Ketuntasan & $81,25 \%$ & Belum Tuntas Klasikal & $100 \%$ & Tuntas Klasikal \\
\hline
\end{tabular}

Berlandaskan rerata nilai hasil belajar dan ketuntasan belajar sebagaimana tersaji pada gambar 4, terlihat dengan jelas peningkatan hasil belajar dan ketuntasan belajar klasikal pada siklus II dibandingkan solusinya berdasarkan hasil pengolahan informasi yang dicari dan dikumpulkannya sendiri sehingga peserta didik memiliki pengetahuan baru yang dapat digunakannya dalam memecahkan persoalan yang relevan. Dengan model ini, pengetahuan dan keterampilan yang diperoleh peserta didik diharapkan bukan hanya dihasilkan dari mengingat seperangkat fakta-fakta, tetapi lebih dari pada itu, yakni dihasilkan dari menemukan sendiri.

Hasil Belajar Peserta Didik dalam Pembelajaran (Materi Teks Biografi) dengan Model Discovery Learning

Berdasarkan hasil penilaian hasil belajar dengan materi teks biografi sebagaimana tersaji pada tabel 4 terlihat dengan jelas kenaikan hasil belajar pada siklus II dibandingkan dengan siklus I. Pada siklus I, nilai tertinggi peserta didik adalah 95 dengan predikat amat baik. meningkat menjadi 100 dengan predikat amat baik pada siklus II; nilai terendah pada siklus I adalah 60 dengan predikat kurang baik meningkat menjadi 78 dengan predikat cukup baik pada siklus II; nilai rata-rata hasil belajar pada siklus I adalah 82 dengan predikat cukup, meningkat menjadi 94 dengan predikat amat baik pada siklus II; dan ketuntasan belajar klasikal pada siklus I adalah $81,25 \%$ dengan indikator belum tuntas meningkat menjadi $100 \%$ dengan indikator tuntas secara klasikal. 
nilai hasil belajar peserta didik sebesar 12 . Pada sisi lain, ketuntasan belajar pada siklus I sebesar $81,25 \%$ dengan kategori belum tuntas secara klasikal meningkat menjadi 100\% dengan kategori tuntas secara klasikal pada siklus II. Terjadi peningkatan ketuntasan belajar sebesar $18,75 \%$.

\begin{tabular}{|c|c|}
\hline & $\square$ Siklus II 口Siklus I \\
\hline Ketuntasan & $\square \square \square$ \\
\hline Belajar & 81,25 \\
\hline \multirow{2}{*}{ Hasil Belajar } & 94 \\
\hline & 82 \\
\hline
\end{tabular}

Gambar 4. Peningkatan Hasil Belajar dan

Ketuntasan Belajar Peserta Didik

Peningkatan nilai hasil belajar peserta didik ini tidak terlepas dari peningkatan kinerja guru dan kinerja peserta didik dalam pembelajaran dengan model discovery learning. Guru telah mampu mengimplementasikan pembelajaran model discovery learning dengan amat baik dan kinerja peserta didik dalam pembelajaran model discovery learning juga baik.

Hasil belajar peserta didik yang meningkat juga disebabkan oleh tanggapan positif peserta didik terhadap pembelajaran dengan model discovery learning. Peserta didik merasa senang dan terlibat aktif dalam pembelajaran. Hasil angket yang diberikan oleh peneliti pada akhir pembelajaran siklus II sebagaimana tersaji pada tabel 5 menunjukkan bahwa respon peserta didik terhadap pembelajaran dengan model discovey learning adalah amat baik, artinya peserta didik menganggap bahwa pembelajaran dengan model discovery learning amat menyenangkan, amat menarik, dan amat inspiratif.

Tabel 5. Tanggapan Peserta Didik terhadap Implementasi Pembelajaran dengan Model Discovery Learning

\begin{tabular}{llcc}
\hline No. & $\begin{array}{c}\text { Respon Peserta Didik dalam Pembelajaran dengan } \\
\text { Model Discovery Learning }\end{array}$ & Jumlah & Persentase \\
\hline 1 & Amat Baik & 22 & $68,75 \%$ \\
\hline 2 & Baik & 10 & $31,25 \%$ \\
\hline 3 & Cukup Baik & 0 & $0 \%$ \\
\hline 4 & Kurang Baik & 0 & $0 \%$ \\
\hline & Respons Peserta Didik & \multicolumn{2}{c}{92} \\
\hline & Predikat & \multicolumn{2}{c}{ Amat Baik } \\
\hline
\end{tabular}

Peserta didik terlibat aktif dalam pembelajaran dengan melakukan aktivitas yang menuntut kemampuan berpikir tinggi, akan tetapi menyenangkan. Oleh karena pembelajaran berorientasi pada keaktifan peserta didik dan peserta didik merasa senang, mereka lebih mudah menguasai materi pembelajaran. Dengan demikian, mereka tidak mengalami kesulitan ketika mengerjakan soal penilaian hasil belajar dan pada gilirannya memperoleh hasil yang optimal.

Tanggapan poisitif terhadap pelaksanaan pembelajaran dengan model discovery learning juga diperkuat dengan jawaban peserta didik atas wawancara yang dilakukan peneliti dengan peserta didik pada akhir pembelajaran pada siklus II sebagaimana disampaikan oleh peserta didik yang bernama E (Kelas X MIPA 5) berikut.

Pembelajaran dengan model discovery learning menjadikan pembelajaran lebih menarik dan menyenangkan mungkin karena kita melakukan interaksi kelompok. Pembelajaran juga melatih peseserta didik untuk berpikir kritis, kreatif, komunikatif, dan kolaboratif karena murid dibiasakan mengerjakan tugasnya secara mandiri dengan bimbingan guru.

(Wawancara dengan E, Jumat, 1 Maret 2019) 
Tanggapan yang hampir sama diungkapkan oleh T (Kelas X MIPA 5)

Pembelajaran dengan model discovery learning menginspirasi karena siswa diarahkan untuk aktif dalam pembelajaran sehingga kemampuan berpikir meningkat. Pembelajaran menyenangkan karena siswa diajak untuk berpikir kritis.Siswa ditantang untuk menemukan materi sendiri tidak hanya diaparkan oleh guru.

(Wawancara dengan T, Jumat, 1 Maret 2019)

Dengan kalimat yang lebih sederhana, G (Kelas X MIPA 5) memberikan tanggapannya sebagai berikut.

Pembelajaran dengan model discovery learning seru, menyenangkan. Pembelajaran lebih menarik dan menyenangkan karena asyik. Kita juga diminta untuk menemukan kesimpulan dan juga berkomunikasi dengan teman/guru.

(Wawancara dengan G, Jumat, 1 Maret 2019)

Hal yang sama disampaikan oleh $\mathrm{V}$ bahwa pembelajaran model discovery learning menarik, menyenangkan, dan melatih berpikir kritis, kreatif, komunikatif, dan kolaboratif sebagaimana penuturannya berikut.

Pembelajaran model discovery learning menarik dan menyenangkan karena kami harus dapat memunculkan pendapat-pendapat kami. Kami juga harus berpikir bersama untuk memecahkan masalah.

(Wawancara dengan V, Jumat, 1 Maret 2019)

Penuturan yang serupa disampaikan oleh AA sebagai berikut.

Pembelajaran model discovery learning menarik dan menyenangkan karena banyak pendapat yang disampaikan mengenai materi yang didiskusikan. Kita juga dituntut untuk menguasai materi sesuai dengan kemampuan masing-masing.

(Wawancara dengan AA, Jumat, 1 Maret 2019)
Impelementasi model pembelajaran discovery learning membuat peserta didik lebih aktif, kritis, dan senang dan pengetahuan yang diperoleh lebih lama diingat sehingga meningkatkan hasil belajar mereka. Hal ini seiring dengan pendapat Hosnan (2014: 282) bahwa discovery learning adalah suatu model untuk mengembangkan cara belajar aktif dengan menemukan sendiri, menyelidiki sendiri sehingga hasil yang diperoleh akan setia dan tahan lama dalam ingatan. Melalui belajar penemuan, peserta didik juga bisa belajar berpikir analisis dan mencoba memecahkan sendiri masalah yang dihadapi. Asumsi ini sejalan dengan pernyataan Wilcox (dalam Hosnan, 2014: 281) bahwa dalam pembelajaran dengan discovery learning, peserta didik didorong untuk belajar sebagian besar melalui keterlibatan aktif mereka sendiri dengan konsep-konsep dan prinsipprinsip dan guru mendorong peserta didik untuk memiliki pengalaman dan melakukan percobaan/pengamatan yang memungkinkan mereka menemukan prinsip-prinsip untuk diri mereka sendiri.

\section{KESIMPULAN}

Model pembelajaran discovery learning dapat meningkatkan kinerja guru dalam pembelajaran, meningkatkan kinerja peserta didik dalam pembelajaran, dan memperoleh respon amat baik dari peserta didik dengan rincian sebagai berikut: a) Rerata nilai kinerja guru dengan model discovery learning pada siklus I sebesar 89 dengan perdikat baik meningkat menjadi 100 dengan predikat amat baik pada siklus II, terjadi peningkatan nilai kinerja peserta didik sebesar 11. b) Rerata nilai kinerja peserta didik dengan model discovery learning pada siklus I sebesar 84,10 dengan perdikat baik meningkat menjadi 88,13 dengan predikat baik pada siklus II, terjadi peningkatan nilai kinerja peserta didik sebesar 4,3. c) Peserta didik menganggap bahwa pembelajaran 
dengan model discovery learning amat menyenangkan, amat menarik, dan amat inspiratif; peserta didik terlibat aktif dalam pembelajaran dengan melakukan aktivitas yang menuntut kemampuan berpikir tinggi, akan tetapi menyenangkan.

Implementasi model pembelajaran discovery learning dalam pembelajaran juga dapat meningkatkan hasil belajar peserta didik. Rerata nilai hasil belajar peserta didik dengan model discovery learning pada siklus I sebesar 82 dengan perdikat cukup, meningkat menjadi 94 dengan predikat amat baik pada siklus II, terjadi peningkatan nilai hasil belajar peserta didik sebesar 12. Pada sisi lain, ketuntasan belajar pada siklus I sebesar $81,25 \%$ dengan kategori belum tuntas secara klasikal meningkat menjadi $100 \%$ dengan kategori tuntas secara klasikal pada siklus II, ketuntasan belajarnya meningkat $18.75 \%$.

Model pembelajaran discovery learning dapat dijadikan sebagai salah satu opsi bagi para guru untuk memperbaiki proses pembelajaran agar hasil belajar meningkat. Dalam pembelajaran dengan model discovery learning, guru berperan sebagai pembimbing dengan memberikan kesempatan kepada peserta didik untuk belajar secara aktif sesuai dengan tujuan pembelajaran. Kegiatan belajar mengajar teacher oriented menjadi student oriented.

Kurikulum 2013 Mata Pelajaran Bahasa Indonesia bertujuan agar peserta didik mampu menyimak, mewicara, membaca, dan menulis. Kompetensi dasar yang dikembangkan berdasarkan keempat keterampilan tersebut saling berhubungan dan saling mendukung pengembangan tiga ranah utamanya, yakni pembelajaran berbahasa, bersastra, dan pengembangan literasi. Oleh karena itu, peserta didik hendaknya senantiasa meningkatkan kompetensi sikap, pengetahuan, dan keterampilannya dalam berbahasa, bersastra, dan berliterasi. Sebagai upaya untuk meningkatkan kemampuan guru dalam menerapkan model pembelajaran discovery learning dan model pembelajaran lain yang berpijak pada pendekatan saintifik, sekolah perlu memberikan fasilitasi berupa pelatihan implemetasi beragam model pembelajaran bagi para guru.

\section{DAFTAR PUSTAKA}

Arikunto.Suharsimi. 2015. Penelitian Tindakan Kelas Edisi Revisi. Jakarta: PT Bumi Aksara.

Departemen Pendidikan dan Kebudayaan. 1990. Kamus Besar Bahasa Indonesia. Jakarta : Gramedia.

Dimyati dan Mudjiono. 2006. Belajar dan Pembelajaran. Jakarta: PT Rineke Cipta.

Djamarah, Syamsul Bahri. 1994. Prestasi Belajar dan Kompetesi Guru. Jakarta : Rineka Cipta,

Hosnan. 2014. Pendekatan Saintifik dan Kontekstual dalam Pembelajaran Abad 21. Bogor: Ghalia Indonesia.

Humalik, Omear. 2007. Proses Belajar Mengajar. Jakarta: Bumi Aksara.

Kementerian Pendidikan dan Kebudayaan Republik Indonesia. 2016. Pedoman Mata Pelajaran Bahasa Indonesia Sekolah Menengah Atas/Madrasah Aliyah (SMA/MA). Jakarta: Kemendikbud.

Kementerian Pendidikan dan Kebudayaan Republik Indonesia. 2015. Bahasa Indonesai SMA/MA/SMK/MAK Kelas $X$. Jakarta: Pusat Kurikulum dan Perbukuan Balitbang,

Kementerian Pendidikan dan Kebudayaan. 2016. Permendikbud Nomor 103 Tahun 2014 tentang Pembelajaran pada Pendidikan Dasar dan Menengah. Jakarta: Kementerian Pendidikan dan Kebudayaan.

Kementerian Pendidikan dan Kebudayaan. 2015. Model-Model Pembelajaran Sekolah Menengah Atas. Jakarta: Kemendikbud.

Kosasih, E. 2014. Jenis-Jenis Teks Analisis Fungsi, Struktur, dan Kaidah serta Langkah Penulisannya dalam Mata 
Pelajaran Bahasa Indonesia SMA/MA/SMK. Bandung: Yrama Widya.

Maharani, Y. B., \& Hardini, I. T. A. (2017). "Penerapan Model Pembelajaran Discovery Learning Berbantuan Benda Konkret untuk Meningkatkan Hasil Belajar IPA". Jurnal Mitra Pendidikan, 1 (5), 249-561.

Pusat Pengembangan Profesi Pendidik. 2014. Materi Pelatihan Guru Implementasi Kurikulum 2013. Jakarta: Kemendikbud

Sani, R. (2014). Pembelajaran Saintifik untuk Implementasi Kurikulum 2013. Jakarta: PT Bumi Aksara.

Sardiman, A.M. 2011. Interaksi dan Motivasi Belajar Mengajar. Jakarta: PT Rajagrafindo.
Slameto. 2010. Belajar dan Faktor-Faktor yang Mempengaruhi. Jakarta: PT Rineka Cipta.

Sudjana, Nana. 2001. Penilaian Hasil Proses Belajar Mengajar. Bandung: PT Remaja Rosdakarya.

Suprijono, Agus. 2010. Cooperative Learning Teori dan Aplikasi. Jakarta: Pustaka Jaya.

Surya, H.M. 2008. Kapita Selekta Kependidikan SD. Jakarta: Universitas Terbuka.

Suherli dkk, 2017. Bahasa Indonesai SMA/MA/SMK/MAK Kelas X. Jakarta: Pusat Kurikulum dan Perbukuan Balitbang, Kemdikbud.

Warso, Agus Wasisto Dwi Doso. 2013. Penelitian Tindakan Kelas. Yogyakarta: Graha Cendekia. 